\title{
$\mathrm{LED}$ 를 이용한 장일 처리가 프리지아(Freesia hybrida) '이본느'의 생육 및 개화에 미치는 영향
}

\author{
이진재", 황지혜 \\ 전라북도농업기술원 원예산업과
}

\section{Effect of Day-length Extension Treatment Using LED on Growth and Flowering of Freesia hybrid 'Yvonne'}

\author{
Jin-Jae Lee* and Ji-Hye Hwang \\ Department of Horticulture, Jeollabuk-do Agricultural Research \& Extension Services, Iksan 570-704, Korea
}

\begin{abstract}
The aim of this study was to determine the effect of day-length extension treatment using LED lighting (blue, green, red, or 3 mixed) on vegetative growth and flowering of freesia 'Yvonne', in comparison to that using glow lamps and metal halide lamps. Lighting treatments were imposed from 5 PM to 8 PM for 150 days from after flower bud differentiation to flowering end. For the period from leaf emergence to floral bud formation, no light source affected plant height but the number of leaves was decreased by the metal halide lamp. The highest SPAD value in the flower bud developing period occurred in the metal halide lamp treatment. The time of flowering was advanced by blue or green LED treatment compared to the no lighting control. The green LED lighting advanced flowering by 6 and 8 days compared to no lighting and metal halide lamp treatment, respectively. The blooming period tended to be shortened by the red LED treatment. As for the flower characteristics of 'Yvonne', floret length and width, and the weight of cut flowers were highest in the metal halide lamp treatment. Red LED decreased corm width and weight of 'Yvonne' while glow lamp decreased height and weight. Starch contents in corm were not influenced by the lighting source. Our results indicate that the green LED lighting advanced the time of flowering and the metal halide lamp was good for cut-flower quality.
\end{abstract}

Additional key words: blue LED, glow lamp, green LED, metal halide lamp, red LED, SPAD, starch content

\section{서 언}

프리지아(Freesia hibrida)는 붓꽃과 프리지아속에 속하 며 8-12개의 소화가 상향 수상꽃차례로 피고 구근은 변형된 줄기가 비대하여 형성된 원추형의 인피구경이며, 정식 후 잎이 분화되는 기간에 줄기 아랫부분이 비대화되면서 신구 가 형성된다(Kawa and De Hertogh, 1992; RDA, 2008). 프 리지아는 가을정식 후 4-7주 사이에는 화아 분화가 이루어 지며(Heide, 1965) 개화기 이후 구근은 비대가 시작될 무렵
휴면에 들어가 봄 철 수확시기가 될 때쯤이면 깊은 휴면상 태가 되고(Kaneko and Imanishi, 1985; RDA, 2008), 여름 동안 고온에 노출되면 자연스럽게 휴면이 타파되며 가을철 저온에 의해 맹아와 화아의 형성이 유도된다(Kosugi, 1953; Lee et al., 1998).

일반적인 식물은 일장에 대한 광주기성을 가지고 있으며 (Garner and Allard, 1920), 일장과 관련하여 이미 오래전부 터 채소, 화훼류 등의 각종 작물에서 수없이 많은 연구들이 이루어져 왔다. 프리지아 역시 일장과 관련해 많은 연구보

\footnotetext{
*Comesponding author: hort@korea.kr

※ Received 29 April 2014; Revised 22 August 2014; Accepted 5 September 2014. 본 연구는 농촌진흥청 에너지절감 기술 및 바이오에너지 개발 공동연구사업(과제번호: PJ0076662010)의 지원에 의해 수행되었음.

(C) 2014 Korean Society for Horticultural Science
} 
고들이 있는데, 프리지아에 단일처리를 하면 화아 분화가 촉진되고(Mansour, 1968), 장일처리를 하면 화아 분화가 지 연되지만 화아 발달이 촉진되어 개화가 앞당겨진다고 하였 으며(De Lint, 1969; Kawata, 1973; Gilbertson-ferris and Wilkins, 1978), Doorduin and Zwinkels(1990)에 의하면 네덜란드 동 절기 화기 발달기에 고압나트륨등으로 16 시간 보광을 할 경 우 절화의 생산량과 품질 향상에 영향을 준다고 하였다.

작물재배용 인공광원으로는 지금까지 형광등, 메탈헬라 이드등, 수은등, 백열등과 고압나트륨등(HPS) 등이 사용되 고 있다. 이러한 광원들은 작물의 생육에 필요한 적색과 청 색의 비율이 적어 광 이용효율이 낮고 열의 방출과 수명이 짧은 단점을 가지고 있다. 이와 같은 이유로 최근 LED 광원 이 주목받고 있으며(Heo et al., 2002), 주로 상추(Lee et al., 2010, 2011b; Oh et al., 2011), 토마토(Kwon et al., 2011) 등 채소에서 식물공장에 많이 적용되고 있는 실정이다. 화훼 에서 LED 적용 연구로는 접목선인장에서 적색 LED가 모구 신장과 황색계통 색 발현에 효과적(Nam et al., 2010)이었다 는 결과와 거베라 조직배양묘의 건물중은 적색 $\mathrm{LED}$ 에서 무 거윘고 온시디움에서는 청, 적색 혼합 $\mathrm{LED}$ 가 화경장, 화수, 화경수 등에서 우수했다는 보고(Lee et al., 2011a)가 있다.

본 실험은 프리지아 ‘이본느’을 가지고 꽃눈이 분화된 이 후부터 개화가 종료될 때까지 장일 처리가 프리지아의 생육 및 개화 반응에 미치는 영향과 구근 생성에 미치는 영향을 알아보고자 최근에 주목 받고 있는 LED등과 기존 인공광원 으로 많이 쓰이던 백열등과 메탈헬라이드를 이용하여 실험 을 수행하였다.

\section{재료 및 방법}

본 연구에 사용된 프리지아는 네덜란드 수입종인 이본느 (Freesia hybrida 'Yvonne') 품종으로 휴면 타파한 구근을 저온처리 하지 않고 최저온도 $9^{\circ} \mathrm{C}$ 가 유지되는 연동형의 가 온 비닐하우스에 정식하여 수행하였다.

시험구는 3 반복으로 완전임의배치 하였으며, 화아 분화 이 후 11월 1일부터 개화가 종료된 3월 31일까지 매일 17:00부 터 3 시간 동안 전조하여 장일 처리를 하였다. 무처리 대조구

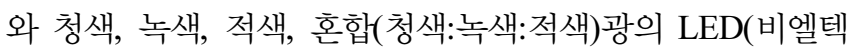
(주과 농진청 공동제작) 그리고 비교 광원으로 백열등과 메탈 헬라이드등을 설치하였고, 광원과 식물체와의 높이는 $1.5 \mathrm{~m}$ 를 유지하였다(Fig. 1). 광 처리 시 대조구는 암막 필름을 사 용하여 자연광 이외에 다른 빛의 간섭을 받지 않게 하였고,
$\mathrm{LED}$ 처리 시 청색광 $(460 \mathrm{~nm})$ 은 $3.11 \mu \mathrm{mol} \cdot \mathrm{m}^{-2} \cdot \mathrm{s}^{-1}$, 녹색광 $(500$ $\mathrm{nm})$ 은 $1.80 \mu \mathrm{mol} \cdot \mathrm{m}^{-2} \cdot \mathrm{s}^{-1}$, 적색광 $(630 \mathrm{~nm})$ 은 $1.28 \mu \mathrm{mol} \cdot \mathrm{m}^{-2} \cdot \mathrm{s}^{-1}$, 혼합광(청색:녹색:적색)은 $2.00 \mu \mathrm{mol} \cdot \mathrm{m}^{-2} \cdot \mathrm{s}^{-1}$ 의 광도를 나타 내었고, 백열등은 $1.64 \mu \mathrm{mol} \cdot \mathrm{m}^{-2} \cdot \mathrm{s}^{-1}$, 메탈헬라이드등은 15.10 $\mu \mathrm{mol} \cdot \mathrm{m}^{-2} \cdot \mathrm{s}^{-1}$ 의 광도를 보였다. 전등은 1 개/평의 기준으로 설치하였다(Table 1).

장일처리에 따른 '이본느' 품종의 생장 변화를 알아보기 위하여 초장, 엽수 및 엽록소 함량(SPAD)을 측정하였다. 초 장과 엽수는 장일처리 후 2주가 경과되었을 때, 2주 간격으 로 4회에 걸쳐 조사하였다. 엽록소 함량은 광원설치 9주가 경과되었을 때 SPAD meter(SPAD-502, Minolta, Japan)를 이용하여 3 번째 잎의 중간부위를 특정하였다. 광원별 장일 처리에 따른 개화반응을 보기 위하여 개화특성을 조사하였 다. 1 번 소화가 착색되어 봉오리가 $1-2 \mathrm{~mm}$ 정도 열개되었을 때를 개화시로 조사하고, 전체 조사 개체의 $80 \%$ 가 개화 되 었을 때를 개화종으로 조사하였다. 1 번화의 첫 번째 소화가 완전히 개화하였을 때 초장, 측지수, 줄기직경, 1 번화의 절 화장, 소화수, 화장, 화폭, $1 \cdot 2$ 번 소화의 간격, 절화중을 측 정하였다.

4월경 개화가 종료된 시점에서 단수하기 시작하여 5 월 초 식물체가 완전히 마른 후 구근을 수확하였다. 장일처리가 신구 형성에 미치는 영향을 알아보기 위하여 모구의 수, 구 고, 구폭, 무게, 자구의 개수와 무게를 조사하였다. 구근 내 전분의 함량은 $40^{\circ} \mathrm{C}$ 에서 건조시킨 구근을 마쇄한 다음 $0.2 \mathrm{~g}$ 을 취해 perchloric $\operatorname{acid}\left(70 \% \mathrm{HClO}_{4}\right) 9.2 \mathrm{~N}$ 과 $4.6 \mathrm{~N}$ 을 용매로 사용하여 추출하였고, Anthrone으로 발색시킨 후 비색계 (Power wave XS2, Bio Tek, USA)를 이용하여 660nm에서 흡광도를 측정하였다(Morris, 1948; MaCready et al., 1950). Glucose(Sigma Chemical Co., USA) 표준용액을 만들어 표

Table 1. Light intensity of LEDs and other lighting types used in this experiment, determined at 6:00 PM.

\begin{tabular}{lcr}
\hline \multirow{2}{*}{ Light resource } & \multicolumn{2}{c}{ Light intensity } \\
\cline { 2 - 3 } & $\mu \mathrm{mol} \cdot \mathrm{m}^{-2} \cdot \mathrm{s}^{-1}$ & \multicolumn{1}{c}{ Lux } \\
\hline Control & 0.01 & 0.5 \\
Blue LED & 3.11 & 159.2 \\
Green LED & 1.80 & 92.2 \\
Red LED & 1.26 & 64.5 \\
Mixed LED & 2.00 & 102.4 \\
Glow lamp & 1.64 & 84.0 \\
Metal halide lamp & 15.10 & 773.2 \\
\hline
\end{tabular}



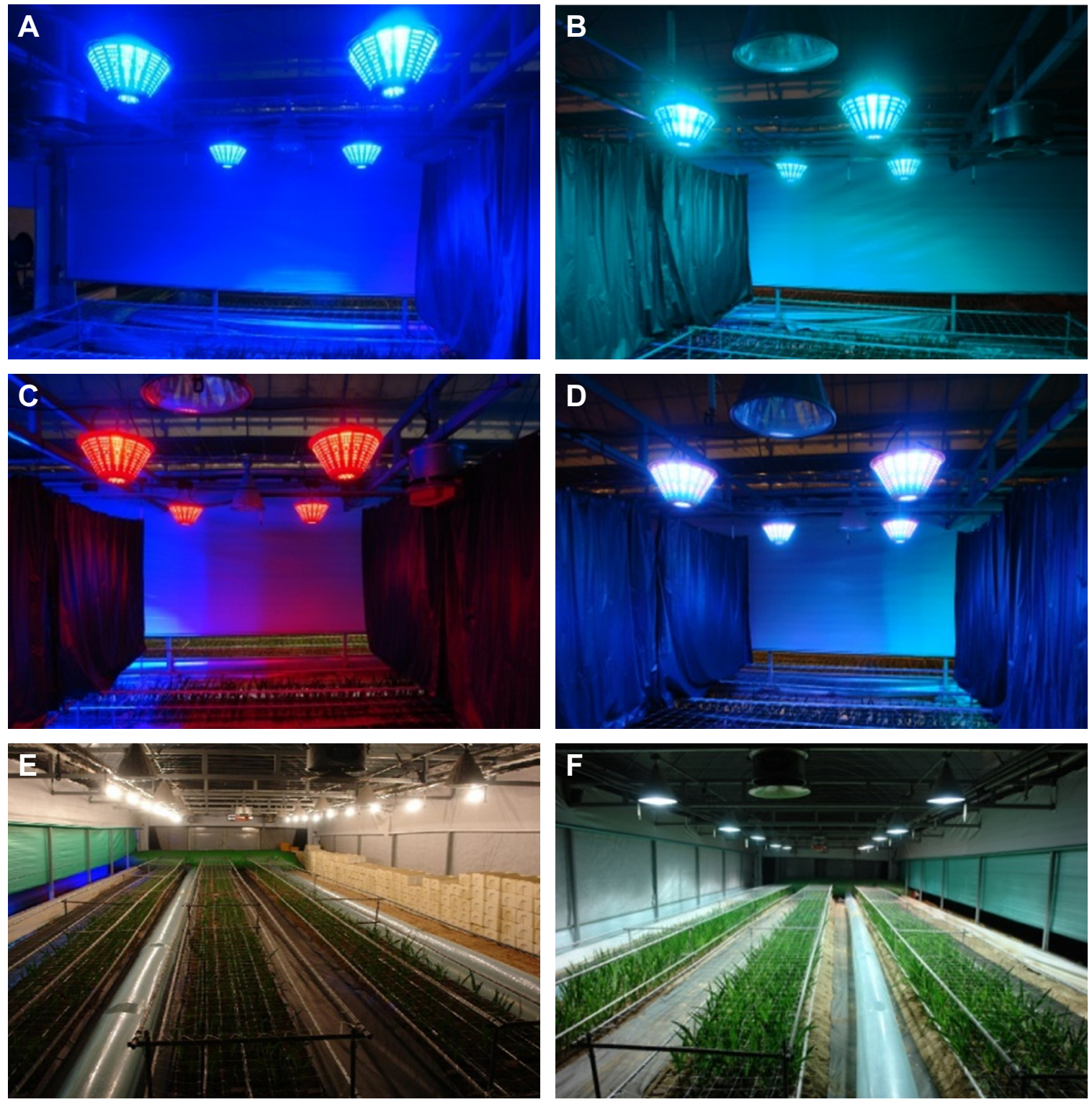

Fig. 1. Day-length extension treatment using LEDs $A=$ blue, $B=$ green, $C=$ red, and $D=$ mixed (blue, green, red), $E=$ glow lamp, and $\mathrm{F}=$ metal halide lamp.

준검량 곡선을 만들었다. 실험 결과에 대한 통계분석은 SAS (SAS Institute Inc., Cary, NC, USA) 9.1 통계프로그램을 이 용하여 $5 \%$ 유의수준으로 실시하였다.

\section{결과 및 고찰}

10 월 15 일 구근을 정식하여 화아가 분화된 이후 11 월 1 일 부터 매일 17 시에서 20시까지 광조사를 하였으며 장일처리 2주가 경과된 11월 15일부터 12월 27일까지 6주 동안 초장
과 엽수의 변화를 관찰하였다(Figs. 2 and 3). 초장은 4주 동 안 처리구간에서 뚜렷한 차이가 관찰되지 않았으나 이후 12 월 27일 조사에서는 메탈헬라이드등(MH) 처리가 $67.2 \mathrm{~cm}$, 적색광 처리가 $66.3 \mathrm{~cm}$ 로 가장 길고, 청색광 처리가 $60.7 \mathrm{~cm}$ 로 가장 짧게 조사되었다.

하지만 무처리와 전체 광원간에 초장에서는 유의성이 없 는 것으로 나타나 $\mathrm{LED}$ 광을 이용한 장일처리가 초장의 증감 에 어떤 효과도 없는 것으로 조사되었다(Fig. 2). 엽수도 무 처리가 5.5 개로 가장 많았고 $\mathrm{MH}$ 등 처리가 4.8 개로 가장 적 
어 처리간 수치적인 차이는 있었으나 처리간 통계적 유의성 은 인정되지 않았다(Fig. 3). 적색광은 광합성에 관여하여 즐 기신장을 촉진시키고, 청색광은 신장을 억제시키지만 식물 의 생육과 형태형성에 중요한 작용을 하는 것으로(Barnes and Bugbee, 1992; Okamoto, 1996; Senger, 1984; Wheeler et al., 1991) 알려져 있고, Lee et al.(2010)은 상추에서 적색 광 처리 시 지상부 생육이 촉진되었고 청색광 처리에서는 엽수를 포함해서 생육이 억제되었다고 보고하여 본 연구와 유사한 결과를 보였다.

SPAD 값은 엽록소 함량과 관계가 있어(Campbell et al., 1990), 인공광원 처리에 따른 엽 내 엽록소함량을 간이 측정 하기 위하여 장일처리 9주째인 1월 4일부터 2주 동안 SPAD 값을 조사하였다(Table 2). $\mathrm{MH}$ 등 처리가 60.6로 가장 높았

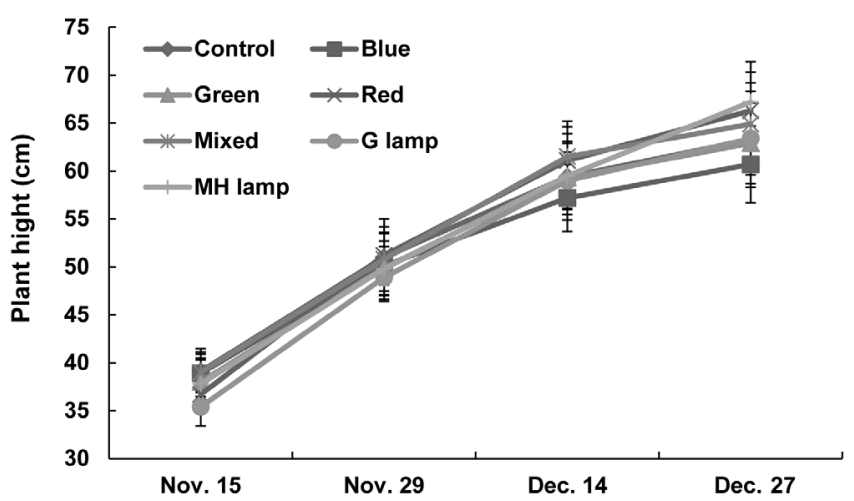

Fig. 2. Change in plant height of 'Yvonne' freesia cultivars treated with LED and other type of lightings. G lamp, glow lamp; MH lamp, metal hailde lamp.

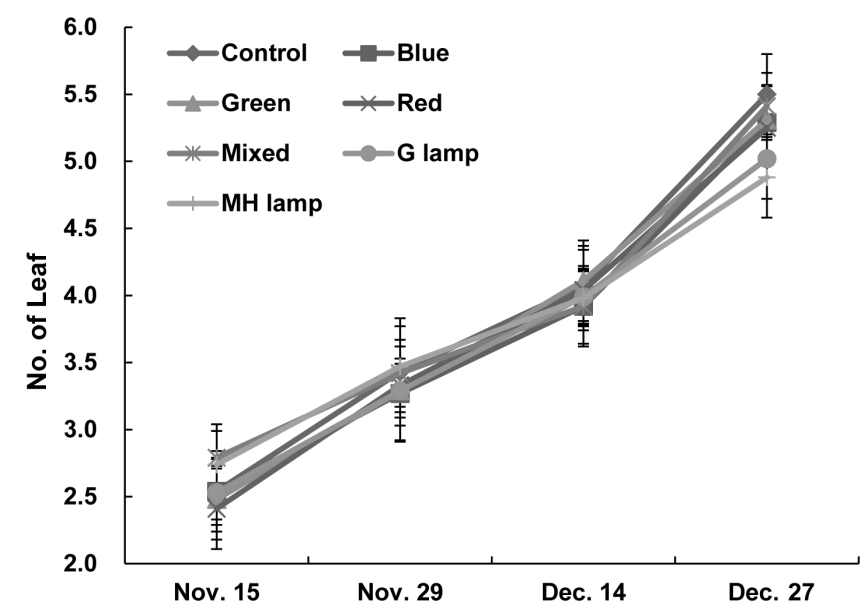

Fig. 3. Change in number of leaves per plant of 'Yvonne' freesia cultivars treated with LED and other type of lightings. G lamp, glow lamp; MH lamp, metal hailde lamp.
고, 무처리와 LED 적색광 처리가 각각 58.5 와 57.3 으로 가 장 낮게 측정되어 유의한 차이를 보였다.

잎은 광합성의 기관으로서 식물체의 구조와 기능적인 면 에서 형태, 생리학적으로 중요하며(Mita and Shibaoka, 1983), 광합성과 엽록소함량 간에는 정의 상관관계가 있다(Jung, 1997).

또한 엽록소 함량은 광도와 광질의 영향을 받는 것으로 알려져 있다(Di Benedetto, 1991). Lee et al.(2011a)의 보고 에 의하면 온시디움을 야간에 4시간 동안 $\operatorname{LED}($ 적색, 청색, 청색/적색의 혼합)를 처리하여 재배하였을 때 $\mathrm{SPAD}$ 값이 높게 측정되었으며 무처리와 백열등에서는 떨어진 것으로 보고하였고, Kim et al.(2009b)은 인삼에 일출 전 3시간 동안 LED 청색/적색과 형광등 처리는 효과가 나타나지 않았지만 LED 적색광과 청색광에서는 엽록소 함량이 높았다고 보고 하였다. 본 연구는 $\mathrm{MH}$ 등 처리에서 $\mathrm{SPAD}$ 값이 상승한 것을 제외하고 광원간에는 $\mathrm{SPAD}$ 값의 증감을 확인할 수 없었으 며, Lee et al.(2011a)의 보고와는 다르게 적색광 처리가 백 열등 처리 보다 도 낮은 측정치를 보였다.

본 실험결과 프리지아 재배에 있어 특정 LED 광질이 엽 록소함량 변화에 미치는 차이를 판단하기 어려웠으며, 광원 간에는 광도가 가장 높게 나타난 MH등 처리에서 엽록소 함 량이 가장 높았고 광도가 가장 낮은 LED 적색광에서 낮게 나타난 것은, 같은 높이로 설치된 광원등에서 나오는 광도 의 영향이 큰 것으로 사료된다.

개화시기를 조사한 결과, $\mathrm{LED}$ 의 청색광과 녹색광 처리에 의해 개화가 앞당겨진 것을 관찰할 수 있었다(Table 3). 특 히 LED 녹색광 처리구가 정식 119 일만에 개화하여 전체 처

Table 2. Changes in SPAD value of 'Yvonne' leaves treated with LEDs and other types of lighting.

\begin{tabular}{lcclc}
\hline \multirow{2}{*}{ Lighting Sources } & \multicolumn{5}{c}{ SPAD value } \\
\cline { 2 - 5 } & Jan. 4 & Jan. 10 & Jan. 17 & Mean \\
\hline Control & $57.3 \mathrm{a}^{\mathrm{y}}$ & $58.4 \mathrm{a}$ & $59.9 \mathrm{a}$ & $58.5 \mathrm{bc}$ \\
Blue LED & $59.0 \mathrm{a}$ & $58.9 \mathrm{a}$ & $58.8 \mathrm{ab}$ & $58.9 \mathrm{abc}$ \\
Green LED & $59.6 \mathrm{a}$ & $57.8 \mathrm{a}$ & $59.5 \mathrm{ab}$ & $59.0 \mathrm{abc}$ \\
Red LED & $57.2 \mathrm{a}$ & $57.9 \mathrm{a}$ & $56.8 \mathrm{~b}$ & $57.3 \mathrm{c}$ \\
Mixed LED & $58.9 \mathrm{a}$ & $57.3 \mathrm{a}$ & $58.8 \mathrm{ab}$ & $58.3 \mathrm{bc}$ \\
G lamp $^{\mathrm{z}}$ & $60.4 \mathrm{a}$ & $60.6 \mathrm{a}$ & $58.7 \mathrm{ab}$ & $59.9 \mathrm{ab}$ \\
MH lamp $^{\mathrm{z}}$ & $60.9 \mathrm{a}$ & $61.3 \mathrm{a}$ & $59.5 \mathrm{ab}$ & $60.6 \mathrm{a}$ \\
\hline
\end{tabular}

${ }^{\mathrm{z}} \mathrm{G}$ lamp (glow lamp) and MH lamp (metal halide lamp). ${ }^{\mathrm{y}}$ Mean separation within columns by Duncans's multiple range test at $5 \%$ level. 
리구 중에서 개화가 가장 빨랐고, 무처리구가 정식 124.7일 만에 개화하여 대조구보다 6일 정도 앞당겨진 것을 확인할 수 있었다(Fig. 4). 생육이 우수한 것으로 조사된 MH등 처 리구는 정식 126.7 일만에 개화해 다른 처리구보다 늦은 경 향이었으며 가장 빨리 개화한 LED 녹색광 처리와는 8 일 정 도 차이가 났다. 개화된 개체 수가 $80 \%$ 가 될 때까지 전체 개화기간을 조사한 결과, 백열등 처리구가 12.7 일로 가장 길 었고 LED 적색광 처리구가 8일로 4.7일간 빨리 개화되어 $\mathrm{LED}$ 적색광이 일시에 전체적으로 개화하는 것으로 조사되
었다(Table 3).

국화재배 시 야간에 $\mathrm{LED}$ 를 전조하였을 때 청색광에서 개 화가 촉진되었으며 적색광에서는 개화가 억제되었고(Kim et al., 2009a), 시클라멘 재배 시 10시간의 LED 청색/적색 처리는 동일한 시간의 LED 청색이나 적색 처리구와는 차이 가 없었으나 형광등 처리구보다는 개화가 월등하게 빨라졌 다는 연구결과도 보고되었다(Heo et al., 2000). 본 실험에서 는 LED 녹색광 처리구가 무처리보다 6일 정도 앞당겨진 것으로 조사되었는데, 여러 분석된 결과로 미루어 개화에

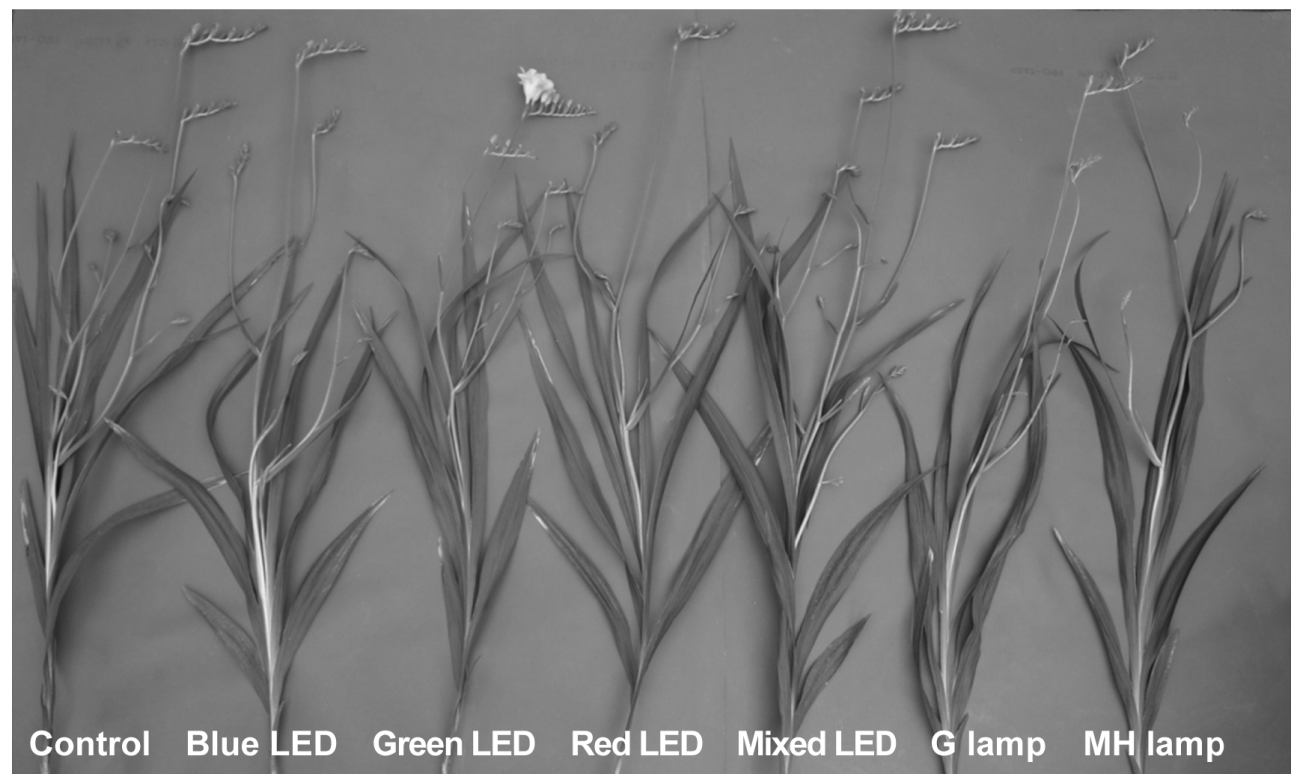

Fig. 4. The green LED lighting advanced time of flowering in 'Yvonne' freesia cultivars treated with LED and other type of lightings. G lamp, glow lamp; MH lamp, metal hailde lamp.

Table 3. Effect of day length extension treatments with LED on time of flowering of 'Yvonne' freesia, compared to glow lamp and metal halide lamp.

\begin{tabular}{lcccc}
\hline \multirow{2}{*}{ Lighting Sources } & \multicolumn{4}{c}{ Days taken since planting } \\
\cline { 2 - 5 } & $\begin{array}{c}\text { Time of emergence } \\
\text { of flower stalk }\end{array}$ & $\begin{array}{c}\text { Time of } \\
\text { flowering }\end{array}$ & $\begin{array}{c}\text { Time of } \\
80 \% \text { flowering }\end{array}$ & $\begin{array}{c}\text { Blooming } \\
\text { period }\end{array}$ \\
\hline Control & $83.7 \mathrm{~cd}^{\mathrm{y}}$ & $124.7 \mathrm{ab}$ & $133.0 \mathrm{ab}$ & $8.3 \mathrm{ab}$ \\
Blue LED & $82.7 \mathrm{~d}$ & $121.0 \mathrm{~cd}$ & $130.0 \mathrm{bc}$ & $9.0 \mathrm{ab}$ \\
Green LED & $81.0 \mathrm{~d}$ & $119.0 \mathrm{~d}$ & $128.0 \mathrm{c}$ & $9.0 \mathrm{ab}$ \\
Red LED & $86.3 \mathrm{bc}$ & $124.0 \mathrm{abc}$ & $132.0 \mathrm{abc}$ & $8.0 \mathrm{~b}$ \\
Mixed LED & $82.3 \mathrm{~d}$ & $121.3 \mathrm{bcd}$ & $131.3 \mathrm{bc}$ & $10.0 \mathrm{ab}$ \\
G lamp & $88.3 \mathrm{ab}$ & $123.3 \mathrm{abc}$ & $136.0 \mathrm{a}$ & $12.7 \mathrm{a}$ \\
MH lamp $^{\mathrm{z}}$ & $91.0 \mathrm{a}$ & $126.7 \mathrm{a}$ & $136.0 \mathrm{a}$ & $9.3 \mathrm{ab}$ \\
\hline
\end{tabular}

${ }^{\mathrm{z}} \mathrm{G}$ lamp (glow lamp) and MH lamp (metal halide lamp).

${ }^{\mathrm{y}}$ Mean separation within columns by Duncans's multiple range test at $5 \%$ level. 
영향을 주는 일부 특정 광질의 효과는 식물 종에 따라 다 른 것으로 판단된다. Lee et al.(2009)의 보고에 의하면 생 육기간 한낮의 광도시험에서 프리지아는 $5,000 \mathrm{Lux}$ 이상의 광도에서 $90 \%$ 이상의 개화율을 보였고 $3,000 \mathrm{Lux}$ 이하에 서는 개화율이 $20 \%$ 이하로 급격히 떨어져, 광도가 개화에 미치는 영향은 $5,000 \mathrm{Lux}$ 이상에서 효과가 있는 것으로 보 고하였다.

본 연구에서 처리 광원별 광도를 보면 $\mathrm{MH}$ 등(773.2Lux) 처리가 다른 광원보다 7-9배 이상 높게 나타났지만 낮 시간 이외에 일장이 연장된 시간에 $1,000 \mathrm{Lux}$ 이하의 광도처리는 개화에 영향을 미치지 못한 것으로 판단된다.

Table 4. Effect of day-length extension treatments with LEDs on plant height, the number of lateral shoots, and stem diameter of 'Yvonne' freesia, compared to to glow lamp and metal halide lamp, determined at the stage of flowering.

\begin{tabular}{lccc}
\hline $\begin{array}{l}\text { Lighting } \\
\text { Sources }\end{array}$ & $\begin{array}{c}\text { Plant height } \\
(\mathrm{cm})\end{array}$ & $\begin{array}{c}\text { No. of } \\
\text { lateral shoots }\end{array}$ & $\begin{array}{c}\text { Stem diameter } \\
(\mathrm{mm})\end{array}$ \\
\hline Control & $97.0 \mathrm{a}^{\mathrm{y}}$ & $5.1 \mathrm{ab}$ & $6.27 \mathrm{ab}$ \\
Blue LED & $94.7 \mathrm{a}$ & $5.0 \mathrm{ab}$ & $6.26 \mathrm{ab}$ \\
Green LED & $97.5 \mathrm{a}$ & $5.1 \mathrm{ab}$ & $5.95 \mathrm{~b}$ \\
Red LED & $98.1 \mathrm{a}$ & $4.9 \mathrm{ab}$ & $6.10 \mathrm{~b}$ \\
Mixed LED & $97.7 \mathrm{a}$ & $5.4 \mathrm{a}$ & $6.34 \mathrm{ab}$ \\
G lamp $^{\mathrm{z}}$ & $88.7 \mathrm{a}$ & $4.8 \mathrm{~b}$ & $5.73 \mathrm{~b}$ \\
MH lamp $^{\mathrm{z}}$ & $99.8 \mathrm{a}$ & $4.6 \mathrm{~b}$ & $7.43 \mathrm{a}$ \\
\hline
\end{tabular}

${ }^{\mathrm{z}} \mathrm{G}$ lamp (glow lamp) and MH lamp (metal halide lamp). ${ }^{\mathrm{y}}$ Mean separation within columns by Duncans's multiple range test at $5 \%$ level.
프리지아의 개화에 미치는 일장의 영향에 관한 지금까지 의 연구결과에 따르면, 단일에 의해 화아 분화가 시작되어 이후 장일에 의해 발달되는 것으로 알려져 있으며(Kosugi, 1953), 단일보다는 장일에서 재배되었을 때 개화일과 개화 기간이 단축되었다(Blom and Piott, 1992)는 보고가 있다. 본 연구결과 프리지아의 개화일을 앞당기는데 있어 효과적 인 LED광은 녹색광이었으며, 장일처리를 통한 개화시기조 절에 있어 일장이나 광도보다는 광질이 더 큰 영향을 미치 는 것으로 판단된다. 녹색광과 프리지아의 개화촉진에 관한 원인을 규명하기 위해서는 좀더 세부적인 연구가 진행되어 야 할 것으로 사료된다.

생육특성 조사는 1 번화의 1 번 소화가 완전히 개화하였을 때 실시하였다. 식물체 초장과 측지수 등은 처리간 통계적 으로 유의적인 차이가 발견되지 않았지만(Table 4), 1 번화의 절화장은 개별 $\mathrm{LED}$ 등보다 백열등에서 작았다(Table 5). 1 번화의 절화장은 백열등 처리구를 제외하고 무처리구 포함 모든 처리구가 $30 \mathrm{~cm}$ 이상으로 조사되었다(Table 5).

소화의 장·폭 조사에서 $\mathrm{MH}$ 등 처리구가 각각 $5.4 \mathrm{~cm}$ 와 $7.0 \mathrm{~cm}$ 로 측정되었으며 전체 처리구 중에서 꽃의 크기가 가 장 컸다. 1 번화 절화중 또한 $\mathrm{MH}$ 등 처리구가 $13.3 \mathrm{~g}$ 으로 가 장 무거웠으나 무처리구와는 유의적 차이는 인정되지 않았 다. 반면 LED 녹색, 청색, 백열등 처리구의 절화중은 $10 \mathrm{~g}$ 으 로 조사되었고 무처리보다 감소한 경향이었다.

프리지아 재배 시 절화장, 절화중, 소화수 등의 양적형질 과 꽃떨이, 초세, 연약도, 꽃대와 잎의 직립성 등의 질적 형 질은 프리지아의 절화품질을 결정한다(RDA, 2008). 프리 지아 재배 시 일장의 길이는 초장, 개화수, 절화의 길이와

Table 5. Effect of day-length extension treatments with LED on flower characteristics of 'Yvonne' freesia, compared to glow lamp and metal halide lamp.

\begin{tabular}{lcccccc}
\hline Lighting sources & $\begin{array}{c}\text { Length of } \\
1^{\text {st }} \text { flower stalk } \\
(\mathrm{cm})\end{array}$ & $\begin{array}{c}\text { No. of } \\
\text { florets }\end{array}$ & $\begin{array}{c}\text { Distance between } \\
1^{\text {st }} \text { and } 2^{\text {nd }} \text { florets } \\
(\mathrm{cm})\end{array}$ & $\begin{array}{c}\text { Floret length } \\
(\mathrm{cm})\end{array}$ & $\begin{array}{c}\text { Floret width } \\
(\mathrm{cm})\end{array}$ & $\begin{array}{c}\text { Wt of cut } \\
\text { flower } \\
(\mathrm{g} \mathrm{FW})\end{array}$ \\
\hline Control & $36.5 \mathrm{a}^{\mathrm{y}}$ & $12.4 \mathrm{a}$ & $1.7 \mathrm{a}$ & $4.9 \mathrm{~b}$ & $6.3 \mathrm{~b}$ & $11.9 \mathrm{ab}$ \\
Blue LED & $35.2 \mathrm{a}$ & $12.2 \mathrm{a}$ & $1.6 \mathrm{a}$ & $5.0 \mathrm{ab}$ & $6.3 \mathrm{~b}$ & $10.7 \mathrm{bc}$ \\
Green LED & $35.4 \mathrm{a}$ & $12.5 \mathrm{a}$ & $1.6 \mathrm{a}$ & $5.2 \mathrm{ab}$ & $6.1 \mathrm{~b}$ & $10.2 \mathrm{c}$ \\
Red LED & $35.7 \mathrm{a}$ & $12.1 \mathrm{a}$ & $1.5 \mathrm{a}$ & $4.9 \mathrm{~b}$ & $6.0 \mathrm{~b}$ & $10.2 \mathrm{c}$ \\
Mixed LED & $33.5 \mathrm{ab}$ & $12.3 \mathrm{a}$ & $1.5 \mathrm{a}$ & $5.2 \mathrm{~b}$ & $6.2 \mathrm{~b}$ & $11.1 \mathrm{bc}$ \\
G lamp & $29.6 \mathrm{~b}$ & $11.6 \mathrm{a}$ & $1.7 \mathrm{a}$ & $5.0 \mathrm{~b}$ & $6.0 \mathrm{~b}$ & $9.8 \mathrm{c}$ \\
MH lamp $^{\mathrm{z}}$ & $33.3 \mathrm{ab}$ & $12.5 \mathrm{a}$ & $1.5 \mathrm{a}$ & $5.4 \mathrm{a}$ & $7.0 \mathrm{a}$ & $13.3 \mathrm{a}$ \\
\hline
\end{tabular}

${ }^{\mathrm{z}} \mathrm{G}$ lamp (glow lamp) and MH lamp (metal halide lamp).

${ }^{\mathrm{y}}$ Mean separation within columns by Duncan's multiple range test at $5 \%$ level. 
무게, 측지수 등에 영향을 미치며(Blom and Piott, 1992; Mansour, 1968), 광도(Lee et al., 2006; Lim et al., 2007)와 광질(Lee et al., 2011a)은 식물의 개화기 형질에 관여하는 것으로 알려져 있다. 본 장일 실험에서는 각 광원마다 프리 지아의 개화기 생육에 미친 영향은 조금씩 다르게 조사되었 으나 전체적으로 볼 때 녹색LED처리에서 개화가 가장 빨랐 고MH등 처리는 개화시는 늦었지만 개화기 생육에는 긍정 적인 영향을 끼쳤다. Bae et al.(2008)이 작약을 노지에서 재 배하였을 때 하우스의 촉성재배보다 작약의 생체중, 경장, 경경이 높게 조사된 것은 개화시기가 늦어질수록 영양생장 기간이 길어지면서 지상부의 생육촉진으로 이어져 결국 줄 기수와 개화줄기수의 증가에 기인하기 때문이라고 한 것과 같이 본 연구에서도 $\mathrm{MH}$ 램프 처리 시 다른 처리구보다 높은 광도의 보광 및 늦은 개화로 인하여 생육이 좋은 영향을 미

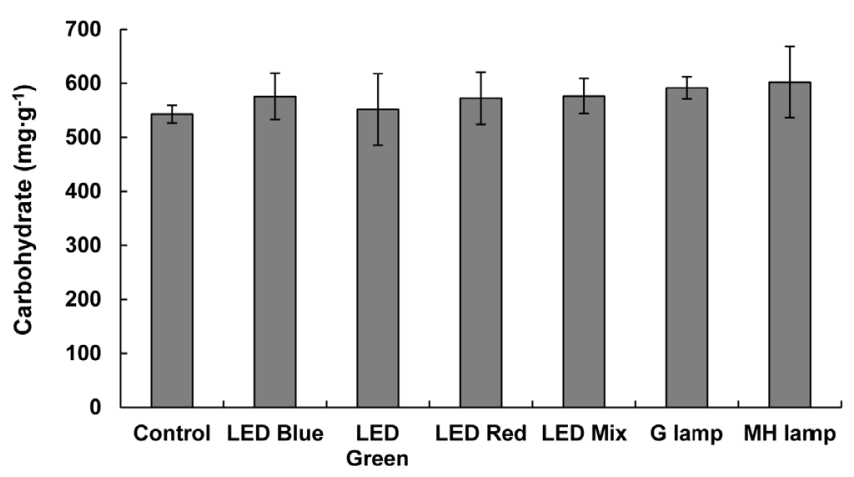

Fig. 5. Effect of day-length extension treatments with LED on carbohydrate of 'Yvonne' freesia corms harvested in early May, compared to glow lamp and metal halide lamp. G lamp, glow lamp; MH lamp, metal halide lamp.
친 것으로 판단된다.

지상부가 완전히 고사한 5월 초순 구근을 수확하였다. 모 구의 조사 결과(Table 6), 구고는 백열등처리구가 $27.98 \mathrm{~mm}$ 로 가장 짧게 측정되어 무처리구와 비교 시 구고의 길이가 감소한 것으로 조사되었다. 무처리구의 구고는 $38.4 \mathrm{~mm}$ 로 가 장 길게 조사되었으나, 백열등 처리구를 제외한 광원 처리구 와 유의적 차이는 나타나지 않았다. 구폭도 마찬가지로 전체 광원간에 크게 차이가 없었으며, LED 적색광 처리구가 무 처리구와 유의적 차이로 구폭이 감소한 것으로 나타났다. 자구의 무게는 전체 처리구간에서 유의적 차이가 관찰되지 않았다(Table 6). 구근 내 전분 함량은 $543-602 \mathrm{mg} \cdot \mathrm{g}^{-1} \mathrm{DW}$ 의 범위로 조사되었으며, 무처리구보다 $\mathrm{LED}$ 를 비롯한 다른 광 원에서의 전분함량이 수치적으로 다소 높게 측정되었지만, 대조구를 포함한 전체 처리구간 통계적 유의성은 없었다 (Fig. 5). 프리지아 구근은 개화기 이후 점차 휴면기에 들어 가면서 전분축적이 이루어지고, 수확시기에는 완전히 휴면 상태가 되며, 휴면이 깊어짐에 따라 구근 내 전분함량도 같 이 증가하는 것으로 알려져 있다(Kaneko and Imanishi 1985; $\mathrm{RDA}, 2008)$. 본 실험에서도 $\mathrm{LED}$ 광원처리가 무처리구와 다른 광원들과 마찬가지로 구근내 전분축척도 양적으로 이 상 없이 잘 이루어진 것으로 분석되었다.

\section{초 록}

본 연구는 프리지아 ‘이본느'를 가지고 매일 오후 5시에 서 8 시까지 150 일 동안 $\mathrm{LED}$ (청색, 녹색, 적색, 청색:녹색:적 색 혼합)광과 백열등, 메탈할라이드등으로 보광을 함으로써,

Table 6. Effect of day-length extension treatments with LED on corm characteristics of 'Yvonne' freesia, compared to glow lamp and metal halide lamp.

\begin{tabular}{lcccccc}
\hline $\begin{array}{l}\text { Lighting } \\
\text { sources }\end{array}$ & $\begin{array}{c}\text { No. of } \\
\text { corms }\end{array}$ & $\begin{array}{c}\text { Corm height } \\
(\mathrm{mm})\end{array}$ & $\begin{array}{c}\text { Corm width } \\
(\mathrm{mm})\end{array}$ & $\begin{array}{c}\text { Corm wt } \\
\text { (g FW) }\end{array}$ & $\begin{array}{c}\text { No of } \\
\text { cormlets }\end{array}$ & $\begin{array}{c}\text { Total wt of } \\
\text { cormlet } \\
\text { (g FW) }\end{array}$ \\
\hline Control & $1.0 \mathrm{a}^{\mathrm{y}}$ & $38.4 \mathrm{a}$ & $30.2 \mathrm{a}$ & $20.4 \mathrm{a}$ & $6.6 \mathrm{a}$ & $10.4 \mathrm{a}$ \\
(g FW/comlet)
\end{tabular}

${ }^{\mathrm{z}} \mathrm{G}$ lamp (glow lamp) and MH lamp (metal halide lamp).

${ }^{\mathrm{y}}$ Mean separation within columns by Duncan's multiple range test at $5 \%$ level. 
꽃눈분화 이후부터 개화가 완전히 종료될 때까지 광질에 따 른 장일처리가 프리지아의 생육 및 개화에 미치는 영향을 알아보기 위하여 수행되었다. 엽분열기부터 화뢰형성기까 지 초장은 광원별 장일처리에 의해 큰 변화는 없었고 엽수 는 메탈할라이드등 처리에서 감소하는 경향이었으나 화뢰 발달기 때 엽 내 엽록소 함량은 메탈할라이드등에서 가장 높았다. LED 청색광과 녹색광에서 개화기가 빨랐는데 특히 녹색광 처리에서 가장 빨라 무처리와 메탈할라이드등에 비 해 6-8일 정도 단축되었다. 포장 내 개화기간은 LED 적색광 에서 가장 짧아 일시 수확에는 효과적이었다. 메탈할라이드 등에서 절화중, 소화의 길이와 폭 등 절화특성이 우수하였 다. 구근의 특성을 조사한 결과 LED 적색광에서는 구폭과 구중이, 백열등 처리에서는 구고와 구중이 감소하였고, 구 근 내 전분함량은 모든 시험구 사이에 특별한 차이가 없었 다. 결과적으로 개화촉진은 $\mathrm{LED}$ 녹색등에서 효과적이었고 개화품질은 메탈할라이드등 처리에서 우수하였다.

추가 주요어 : 청색 LED, 백열등, 녹색 LED, 메탈할라이드 등, 적색 $\mathrm{LED}$, 엽록소함량, 전분함량

\section{인용문헌}

Bae, S.G., J.H. Kim, S.J. Park, J.C. Kim. 2008. Influence of forcing cultivation time on cut flower, root quality, and yield in peony (Paeonia lactiflora Pall. Cv. Taeback). J. Medical CropSci. 16:421-426.

Barnes, C. and B. Bugbee. 1992. Morphological responses of wheat to blue light. J. Plant Physiol. 139:339-342.

Blom, T.J. and B.D. Piott. 1992. Assimilative lighting with highpressure sodium lamps reduces freesia quality. HortScience 27:1267-1268.

Campbell, R.J., K.N. Mobly, R.P. Marini, and D.G. Pfeiffer. 1990. Growing conditions alter the relationship between SPAD-501 values and apple leaf chlorophyll. HortScience 25:330-331.

De Lint, P.J.A.L. 1969. Flowering in freesia: Temperature and corms. Acta Hortic. 14:125-131.

Di Benedetto, A.H. 1991. Light environment effects of chlorophyll content Aglaonema Commuratum. J. Horticultural Sci. Bio. 66:283-289.

Doorduin, J.C. and G.A.M. Zwinkels. 1990. Assimilation lighting for freesia. Positive effects in every respect. Vakblad voor de Bloemisterij 45:42-43.

Garner, W.W. and H.A. Allard. 1920. Effect of the relative length of day and night and factors of the environment on growth and reproduction in plants. J. Agr. Res. 18:553-606.

Gilbertson-ferris, T.L. and H.F. Wilkins. 1978. Flower production of freesia hybrid seedlings under night interruption lighting and short day influence. J. Amer. Soc. Hort. Sci. 103:587-591.

Heo, J.W., C.W. Lee, D. Chakrabarty, and K.Y. Paek. 2002. Growth responses of marigold and salvia bedding plant as affected by monochromatic or mixture radiation provided by a light-emitting diode (LED). Plant Growth Regulat. 38:225-230.

Heo, J.W., C.W. Lee, and K.Y. Park. 2000. Flowering and growth of 'Dixie White' cyclamen miniature influenced by control of light quality and day length using light-emitting diode. Annual Res. Rpt. 5:160-165.

Heide, O.M. 1965. Factors controlling flowering in seed-raised freesia plant. J. Hort. Sci. 40:267-284.

Jung, E.Y. 1997. Effect of leaf-cutting on chlorophyll content, photosynthetic rate and growth by leaf order of phaseolus vulgaris plant. M.S. Thesis Kunghee Univ., Seoul, Korea.

Kaneko, E. and I. Imanishi. 1985. Changes in the depth of dormancy in freesia corms during growth and storage. J. Jap. Soc. Hort. Sci. 54:388-392.

Kawata, J. 1973. Year-round production of freesia in Japan. Jap. Agr. Res. Quart. 7:257-262.

Kawa, L. and A. De Hertogh. 1992. Scanning electron microscopy of floral development in freesias. HortScience 27:1133-1134.

Kim, B.S., K.C. Cho, I.T. Hwang, S.C. Hong, H.G. Kim, G.Y. Gi, B.K. Yun, J.G. Kim, and J.H. Lee. 2009a Effect of light emitting diode (LED) on the flowering of Dendranghema grandiflorum cv. 'Baekma'. Kor. J. Hort. Sci. Technol. 27(Suppl. II):119-120. (Abstr.)

Kim, M.J., X. Li, J.S. Han, S.E. Lee, and J.E. Choi. 2009b. Effect of blue and red LED irradiation on growth characteristics and saponin contents in Panax ginseng C. A. Meyer. Kor. J. Medicinal. Crop Sci. 17:187-191.

Kosugi, K. 1953. Studies on flower-bud differentiation and development in the freesia. I. On the time of flower-bud differentiation and process of flower-bud development. J. Jpn. Soc. Hort. Sci. 22:61-63.

Kwon, J.H., J.S. Park, Y.I. Kang, and H.G. Choi. 2011. Effect of LED light source and intensity on growth and quality of greenhouse grown tomato. Kor. J. Hort. Sci. Technol. 29 (Suppl. II):74. (Abstr.)

Lee, H.S., S.J. Kim, W.G. Shin, and B.C. Yoo. 2006. Effect of light intensity on growth characteristic and flower color change of new Guinea impatiens 'Fishlimp 149'. J. Bio-Environ. Cont. 15:406-411. 
Lee, J.G., S.S. Oh, S.H. Cha, Y.A. Jang, S.Y. Kim, Y.C. Um, and S.R. Cheong. 2010. Effects of red/blue light ratio and short-term light quality conversion on growth and anthocyanin contents of baby leaf lettuce. J. Bio-Environ. Cont. 19:351-359.

Lee, J.J., C.S. Kim, S.Y. Jin, and J.C. Kim. 2009. Effect of different intensity of light treatment on growth and flowering in freesia "Yvonee" and "Shinygold". 2009 Plant Sci. Conf. p. 221.

Lee, J.J., J.S. Jeong, and J.C. Kim. 1998. Effect of high-temperature storage and ethylene on breaking dormancy of freesia corms. J. Kor. Soc. Hort. Sci. 39:789-793.

Lee, J.W., J.H. Kim, S.D. Kim, Y.J. Kim, S.D. Kim, and K.Y. Paek. 2011a. Effect of LED as light quality on growth and flowering of oncidium. Kor. J. Hort. Sci. Technol. 28(Suppl. II):153. (Abstr.)

Lee, S.W., S.D. Lee, S.Y. Sim, H.I. Chung, S.K. Kim, and J.W. Lim. 2011b. Variation of photosynthetic rate of lettuce in different microclimatic conditions for plant factory. Kor. J. Hort. Sci. Technol. 29:(Suppl. II):40. (Abstr.)

Lim, H.H., M.H. Kim, and K.W. Kim. 2007. Effect of light intensity on flower bud development and flowering in perennial Korean native plants. Flower Res. J. 15:72-77.

MaCreedy, R.M., J. Guggolz, V. Silveria, and H.S. Owns. 1950. Determination of starch and amylose in vegetables. Anal. Chem. 22:1156-1158.

Mansour, B.M.M. 1968. Effect of temperature and light on growth, flowering and corm formation in freesia. Ph.D. Thesis Wageningen Agricultural Univ., Netherlands.
Mita, T. and H. Shibaoka. 1983. Change in microtubules in onion leaf sheath cells during bulb development. Plant Cell Physiol. 24:109-117.

Morris, D.L. 1948. Quantitative determination of carbohydrate with for maximum color formation among different carbohydrates and Dreywood's anthrone reagent. Science 107:254-255.

Nam, S.Y., S.M. Park, and B.Y. Yi. 2010. Effect of globe growth and chromogenic on day and night temperature and the LED light treatment of export grafted cactus (Chamecereus silvestrii f. variegate) cultivar. 'Hee-Mang'. Kor. J. Hort Sci. Technol. 28(Suppl. II):115. (Abstr.)

Oh, J.Y., B.J. Lee, W.I. Kim, Y.B. Kim, and G.M. Shon. 2011. Effect of various intensity of radiation an element of light (LED) and treatment time on growth and photosynthetic rate of lettuce plug seedling. Kor. J. Hort. Sci. Technol. 29(Suppl. II):66. (Abstr.)

Okamoto, K., T. Yangi, S. Tanaka, T. Higuchi, Y. Ushida, and H. Watanabe. 1996. Development of plant growth apparatus using blue and red LED as artificial light source. Acta Hort. 440:111-116.

Rural Development Administration (RDA). 2008. Freesia. RDA, Suwon, Korea.

Senger, H. 1984. Blue light effects in biological systems. SpringerVerlag, Berlin, Germany.

Wheeler, R.M., C.L. Mackowiak, and J.C. Sager. 1991. Soybean stem growth under high-pressure sodium with supplemental blue lighting. Agron. J. 83:903-906. 